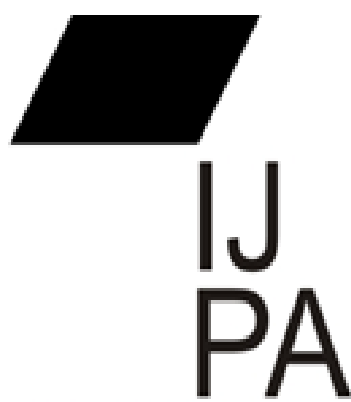

ISSN $2460-0369$

\section{IMPLEMENTASI STANDAR PELAYANAN MINIMAL PENDIDIKAN DASAR (SPM- DIKDAS) TINGKAT SMP (STUDI PADA SMP N 6 SATU ATAP REMBANG DAN SMP N 3 PURBALINGGA)}

\author{
Teguh Prasetya, Muslih Faozanudin, \\ Dyah Retna Puspita \\ Program Pascasarjana Ilmu Administrasi \\ Universitas Jenderal Soedirman \\ prasetya.teguh68@yahoo.com
}

Abstract: Implementation of minimum service standards of basic education (SPM Dikdas) policy of junior high school level in Purbalingga has ups and downs in its development, sometimes up sometimes down, so it is interesting to examine how the implementation process is run. For that, the case study technique was taken in two junior high schools, they are SMP N 6 Satu Atap Rembang Purbalingga and SMP N 3 Purbalingga.The purpose of this research is to analyze the extent of the process of implementation SPM Dikdas policy in SMP N 6 Satu Atap Rembang Purbalingga and SMP N 3 Purbalingga. This research use is Qualitative Descriptive method with purposive sampling technique. The results of this study indicate that the implementation process of SPM Dikdas in SMP N 6 Satu Atap Rembang has not run well because it is still lack of manpower in the Administration Section in SMP N 6 one Roof Rembang while while in SMP N 3 Purbalingga has been run quite well run by the actors. The purpose of the SPM Dikdas Implementation Program is Sufficiently clear, but sometimes the objectives are not achieved maximally because the planned activities that are made still seem less bold because hampered by the tight rules and availability of funding sources. The development of MSS program in SMP level is quite good, but still less quickly because it is hindered by human resources that still do not meet the criteria of SPM Dikdas indicator. The other parties have participated well enough but there needs to be better coordination between the parties so that there is a better communication relationship to accelerate the process of program implementation and the uncontrollable factors experienced by the implementors are funding factors and natural factors which also includes the factors that greatly affect the process of implementation of SPM Dikdas.

Keywords: Policy of SPM Dikdas, Implementation Process 
Abstrak: Implementasi Kebijakan Standar Pelayanan Minimal Pendidikan Dasar (SPM Dikdas) Tingkat Sekolah Menengah Pertama di Kabupaten Purbalingga mengalami pasang surut dalam perkembangannya, kadang naik kadang turun, sehingga menarik untuk diteliti seperti apa proses implementasi dijalankan. Untuk itu diambil teknik studi kasus pada dua sekolah menengah pertama, yaitu SMP N 6 Satu Atap Rembang Purbalingga dan SMP N 3 Purbalingga. Tujuan penelitian ini adalah untuk menganalisis sejauh mana proses iplementasi SPM Dikdas Tingkat SMP N 6 Satu Atap Rembang Purbalingga dan SMP N 3 Purbalingga.Metode penelitian yang penulis gunakan adalah metode Deskriptif Kualitatif dengan teknik pemilihan informan purposive sampling. Hasil penelitian ini menunjukan bahwa proses implementasi SPM Dikdas di SMP N 6 Satu Atap Rembang belum berjalan baik karena masih kekurangan tenaga pada Bagian Tata Usaha di SMP N 6 satu Atap Rembang sedangkan sedangkan pada SMP N 3 Purbalingga sudah berjalan cukup baik dijalankan oleh para aktor. Tujuan Program Implementasi SPM Dikdas Sudah Cukup Jelas, namun adakalanya tujuan tidak tercapai secara maksimal karena rencana kegiatan yang dibuat masih terkesan kurang berani karena terhambat oleh ketatnya aturan dan ketersediaan sumber dana. Perkembangan program SPM Dikdas Tingkat SMP sudah cukup baik, namun masih kurang cepat karena terhalang oleh sumber daya manusia yang masih belum memenuhi kriteria indikator SPM Dikdas. Pihak-pihak lain sudah berpartisipasi cukup baik namun demikian perlu koordinasi yang lebih baik antar pihak-pihak tersebut sehingga terjadi hubungan komunikasi yang lebih baik untuk memprcepat proses implementasi program dan Faktor-faktor yang tak terkendali yang dialami oleh para implementor adalah faktor dana dan faktor alam yang juga termasuk faktorfaktor yang sangat mempengaruhi proses implentasi SPM Dikdas.

Kata Kunci: Kebijakan SPM Dikdas, Proses Implementasi 


\section{PENDAHULUAN}

Kualitas pendidikan di Indonesia masih rendah, untuk itu perlu ditingkatan secara bertahap. Oleh karena itu pemerintah telah menetapkan Standar Nasional Pendidikan (SNP) melalui Peraturan Pemerintah Nomor 15 Tahun 2015 junto PP No.19 tahun 2005 sebagai kriteria minimal yang harus dicapai oleh sistem pendidikan di Indonesia secara menyeluruh di wilayah hukum Negara Kesatuan Republik Indonesia. Mengingat kondisi satuan pendidikan yang pada saat ini sebagian besar masih di bawah SNP dan pemenuhan standar nasional masih dirasakan sulit bagi banyak sekolah/madrasah, maka perlu dicari strategi untuk mencapai SNP secara bertahap, yaitu dengan mengeluarkan Peraturan Pendidikan Nasional No.15 Tahun 2010 junto Peraturan Menteri Pendidikan dan Kebudayaan Nomor 23 Tahun 2013 tentang tentang Standar Pelayanan Minimal Pendidikan Dasar (SPM-Dikdas) sebagai tahapan awal untuk mencapai SNP dan standar lainnya. Apabila SPM Pendidikan telah tercapai maka indikator tingkat layanan akan dinaikkan dari waktu ke waktu hingga pada akhirnya mencapai tingkatan yang ditetapkan dalam SNP atau bahkan melampaui atau di atas SNP.

Oleh karena itu SPM-Dikdas dapat diartikan sebagai upaya dan strategi yang dilakukan pemerintah untuk mencapai SNP secara bertahap dan merupakan sasaran antara menuju pemenuhan SNP. Oleh karenanya SPM-Dikdas sebagai tingkat layanan minimal harus dipenuhi oleh setiap satuan pendidikan. Apabila SPM pendidikan telah tercapai maka indikator tingkat (mutu) layanan akan dinaikkan dari waktu ke waktu hingga pada akhirnya mencapai tingkatan yang ditetapkan dalam SNP.

Untuk mencapai tujuan tersebut, pemerintah kabupaten/kota wajib melakukan pengembangan kapasitas untuk mencapai SPM, sedangkan pemerintah dalam hal ini Kementerian Pendidikan dan Kebudayaan memfasilitasi pengembangan kapasitas melalui peningkatan kemampuan sistem, kelembagaan, personil dan keuangan, baik ditingkat pusat, Provinsi, Kabupaten/Kota dan satuan pendidikan, sebagaimana telah diatur di dalam Peraturan Menteri Pendidikan dan Kebudayaan Nomor 23 Tahun 2013 bahwa penyelenggaraan pendidikan dasar sesuai SPM merupakan kewenangan Kabupaten/Kota. 
Implementasi SPM-Dikdas meliputi implementasi SPM pada jenjang pendidikan Sekolah Dasar (SD) dan Sekolah Menengah Pertama (SMP). Dalam hal ini, peneliti akan menganalisis proses implementasi SPM-Dikdas tingkat SMP, karena peneliti menganggap bahwa jenjang SMP merupakan jenjang penentu seorang siswa untuk menentukan jenis pendidikan berikutnya, apakah dia akan masuk ke sekolah umum atau sekolah kejuruan.

Berdasarkan data pada Dinas Pendidikan Kabupaten Purbalingga di sebutkan bahwa Capaian SPM tingkat Sekolah Menengah Pertama (SMP/MTS) Kabupaten Purbalingga pada tahun 2015 telah mencapai 64,82\%, namun menurun 6,9\% pada tahun 2016 menjadi 57,92\%. Berikut data capaian SPM-Dikdas Tingkat SMP Kabupaten Purbalingga.

Tabel.1 Data Capaian SPM Dikdas Tingkat SMP Kabupaten Purbalingga Tahun 2015-2016

\begin{tabular}{lccc}
\hline \multicolumn{1}{c}{ Tahun } & $\mathbf{2 0 1 5}$ & $\mathbf{2 0 1 6}$ & $+/-$ \\
\hline Jumlah IP & 2204 & 1969,3 & $-234,7$ \\
Rata-rata IP & $64,82 \%$ & $57,92 \%$ & $-6,90 \%$ \\
\hline
\end{tabular}

(Sumber : Dinas Pendidikan Kabupaten Purbalingga)

Data tersebut menunjukkan bahwa proses implementasi SPM Kabupaten Purbalingga dari tahun 2015 sampai 2016 mengalami penurunan hingga 6,9\%. Fenomena tersebut menarik peneliti untuk menganalisis sejauh mana proses implementasi SPM Dikdas tingkat SMP di Kabupaten Purbalingga.

Dalam penelitian ini, diambil teknik studi kasus pada 2 (dua) Sekolah Menengah Pertama (SMP), yaitu : SMP N 6 Satu Atap Rembang Purbalingga dan SMP N 3 Purbalingga. Peneliti mengambil SMP N 6 Satu Atap Rembang Purbalingga karena SMP ini terletak di daerah terpencil di pinggiran hutan, yaitu terletak di Desa Tanalum Kecamatan Rembang Purbalingga dan memiliki capaian SPM yang masih rendah, bahkan gedung pun belum punya karena masih satu atap dengan SD N 1 Tanalum, juga termasuk sekolah termuda di Kecamatan Rembang Kabupaten Purbalingga yang berdiri tahun 2009 dengan jumlah guru semuanya masih wiyata bakti, belum ada satu guru pun yang PNS. Sedangkan untuk SMP N 3 Purbalingga mengapa diambil sebagai obyek penelitian, yaitu karena SMP N 3 Purbalingga termasuk SMP unggulan yang terletak di Pusat Kota Kabupaten 
Purbalingga (Sebelah utara Alun-alun Purbalingga kurang lebih berjarak $100 \mathrm{~m}$ berdempelan persis dengan Kantor Kabupaten Purbalingga) dan merupakan Sekolah yang sudah memiliki capaian SPM tinggi yang memiliki gedung dan sarana dan prasaran sekolah yang lengkap karena juga termasuk sekolah yang mapan yang sudah lama berdiri di Kabupaten Purbalingga dengan jumlah guru PNS yang cukup untuk mengampu semua mata pelajaran yang ada.

Berikut data Indeks Pencapaian (IP) Standar Pelayanan Minimal Pendidikan Dasar SMP N 3 Purbalingga dan SMP N 6 Rembang Purbalingga Tahun 2016 menurut Dinas Pendidikan Kabupaten Purbalingga :

Tabel 2. Data Pencapaian Standar Pelayanan Minimal Pendidikan Dasar SMP N 6 Satu Atap Rembang Purbalingga dan SMP N 3 Purbalingga Tahun 2016

\begin{tabular}{cccc}
\hline IP & URAIAN & $\begin{array}{c}\text { SMP N 6 } \\
\text { Rembang }\end{array}$ & $\begin{array}{c}\text { SMP N 3 } \\
\text { Purbalingga }\end{array}$ \\
\hline 30 & Jumlah & 12 & 30 \\
\hline & Rata-rata & 0,4 & 1 \\
\hline & Prosentase & $40 \%$ & $100 \%$ \\
\hline
\end{tabular}

Dari data tersebut di dapatkan informasi bahwa indeks capain SPM Dikdas untuk SMP N 6 Satap Rembang pada tahun 2016 baru mencapai 40\% sedangkan SMP N 3 Purbalingga sudah mencapai 100\%. Sehubungan dengan hal tersebut, menarik untuk dianalisis "Sejauh Mana Proses Implementasi Standar Pelayanan Minimum Pendidikan Dasar (SPM-Dikdas) Tingkat Sekolah Menengah Pertama (SMP) Di SMP N 6 Satu Atap Rembang Purbalingga dan SMP N 3 Purbalingga?". Penelitian ini bertujuan untuk menganalisis proses Implementasi Standar Pelayanan Minimum Pendidikan Dasar (SPM-Dikdas) Tingkat Sekolah Menengah Pertama (SMP) studi pada SMP N 6 Satu Atap Rembang Purbalingga dan SMP N 3 Purbalingga.

\section{TINJAUAN PUSTAKA}

Implementasi kebijakan adalah proses pelaksanaan kebijakan segera setelah penetapan peraturan atau undang-undang. Implementasi merupakan pelaksanaan undang-undang dimana berbagai aktor, organisasi, prosedur dan teknik bekerja bersama-sama menjalankan kebijakan guna mencapai tujuan-tujuan 
kebijakan atau program-program kebijakan. Menurut Lester dan Stewart (dalam Winarno 2007:144-145) Implementasi yaitu fenomena yang kompleks yang dapat dipahami sebagai proses, output maupun sebagai outcome.

Ripley dan Franklin (dalam Winarno 2007: 145) berpendapat bahwa implementasi adalah apa yang terjadi setelah undang-undang ditetapkan yang memberikan otoritas, kebijakan, keuntungan (benefit) atau keluaran yang nyata (tangible output). Implementasi menunjuk pada sejumlah kegiatan yang sesuai dengan tujuan-tujuan program dan hasil-hasil yang diinginkan oleh para pejabat pemerintah.

Sedangkan Van Meter dan Van Horn (dalam Wibawa, 1978 : 70) mendefinisikan implementasi kebijakan sebagai proses berbagai kegiatan yang dilakukan oleh pemerintah dan swasta (baik secara individu maupun kelompok) untuk mencapai tujuan dan sasaran yang telah ditetapkan. Definisi tersebut memberikan makna bahwa tindakan-tindakan tersebut adalah suatu upaya untuk mentransformasikan keputusan-keputusan yang tertuaang dalam dokumen kebijakan (secara tertulis) menjadi pola-pola operasional dan kegiatan-kegiatan yang nyata (real) dilapangan dalam rangka mencapai perubahan (berupa tujuan dan sasaran), baik yang besar maupun yang kecil, yang diamanatkan oleh isi kebijakan.

Berdasarkan berbagai pendapat para ahli tersebut di atas, dapat disimpulkan bahwa implementasi kebijakan adalah proses realisasi dari berbagai perencanaan yang telah ditetapkan pemerintah oleh para implementor untuk mencapai tujuan-tujuan atau program-program kebijakan yang telah ditetapkan.

Lebih lanjut tentang Implementasi, Ripley dan Franklin (dalam Purwanto, 2012:69) mengatakan bahwa terdapat dua perspektif untuk menganalisis implementasi program, yaitu prespektif complience (kepatuhan) dan what's happening (apa yang terjadi). Perspektif complience biasa disebut dengan pendekatan top-down memahami keberhasilan implementasi dalam arti sempit, yaitu sebagai kepatuhan para implementor dalam melaksanakan kebijakan yang tertuang dalam dokumen kebijakan (dalam bentuk undang-undang, peraturan pemerintah dan program). 
Selain itu, perspektif complience mengkaji implementasi kebijakan dalam lingkup kepatuhan para aktor implementasi kebijakan terhadap hal-hal yang telah ditetapkan dalam aturan kebijakan. Perspektif ini berasumsi masalah kebijakan dilihat sangat hitam putih dan positivistik karena jika kriteria dalam guideline tidak dilaksanakan maka dengan mudah implementasi dinyatakan gagal (Indiahono, 2009:144).

Sedangkan perspektif What's happening atau disebut juga dengan pendekatan bottom-up memahami implementasi kebijakan secara lebih luas tidak hanya mengacu pada kepatuhan para implementornya saja. Menurut Ripley dan Franklin (dalam Winarno 2007: 145) terdapat 5 vaiabel dalam menjalankan pendekatan what,s happening yaitu :

1. Aktor-aktor yang terlibat (The Profusion of Actors)

Dalam tahapan implementasi, terdapat berbagai aktor yang terlibat. Yang dimaksudkan aktor dalam proses implementasi kebijakan adalah pemerintah dan swasta (baik secara individu atau sekelompak) yang terlibat secara langsung dalam setiap kegiatan proses implementasi kebijakan (van Meter dan Van Horn dalam Wibawa, 1978 :70). Ahli lain, Kusumanegara menambahkan bahwa aktor-aktor kebijakan bisa berasal dari berbagai macam lembaga yang tercakup dalam supra struktur politik maupun infra struktur. Para aktor tersebut masing-masing mempunyai karakteristik sendiri yang menunjukkan kekuatan perannya dalam proses implementasi kebijakan (Kusumanegara, 2010:53). Lebih lanjut Ripley dan Franklin menyatakan bahwa semakin kompleks suatu program yang dijalankan oleh pemerintah, maka semakin banyak aktor yang terlibat. Kurangnya personil yang terlatih dengan baik akan menghambat pelaksanaan kebijakan. Pelaksana kebijakan (para aktor) harus memiliki keterampilan yang diperlukan untuk melaksanakan pekerjaan. Variabel ini meliputi:

a. Jumlah aktor dan identitas masing-masing aktor

b. Peran dari masing-masing aktor yang terlibat dalam proses implementasi kebijakan (Ripley dan Franklin, 1986:11) 
Menurut Ripley dan Franklin (dalam Winarno 2007: 145) bahwa Keberhasilan impelementasi suatu program sangat ditentukan oleh peran aktif masingmasing aktor dari tingkat pusat sampai paling bawah.

2. Kejelasan Tujuan dan Sasaran (The Multiplicity and Vagueness of Goals) Menurut Van Meter dan Van Horn bahwa kebijakan publik harus memiliki sasaran kebijakan (tujuan) yang jelas dan terukur. Dengan demikian, tujuannya dapat terwujud. Jika sasaran kebijakan tidak jelas bisa terjadi multiinterpretasi dan mudah menimbulkan kesalahpahaman dan konflik diantara para agen implementor. (Van Meter dan Van Horn : 1975). Sedangkan Edward III (dalam Subarsono, 2006:90-92) mengatakan bahwa apa yang menjadi tujuan dan sasaran kebijakan harus ditransmisikan kepada kelompok sasaran (target group) sehingga akan mengurangi distorsi implementasi. Apabila tujuan dan sasaran kebijakan tidak jelas atau bahkan tidak diketahui sama sekali oleh kelompok sasaran maka kemungkinan akan terjadi resistensi dari kelompok sasaran. Kejelasan dan konsistensi tujuan dapat dipahami sebagai kejelasan isi kebijakan. Menurut Ripley dan Franklin (dalam Winarno 2007: 145) bahwa semakin jelas dan rinci sebuah kebijakan maka akan semakin mudah kebijakan tersebut diimplementasikan karena implementor mudah memahami dan menerjemahkan dalam tindakan nyata, sebaliknya ketidakjelasan isi kebijakan merupakan potensi lahirnya distorsi dalam implementasi kebijakan.

3. Perkembangan dan Kerumitan Program (The Proliferation and Complexity of Government Programs)

Perkembangan adalah perubahan yang berkesinambungan ke arah lebih baik atau progres dalam suatu proses implementasi program sejak program itu dibuat atau ditetapkan. Menurut Westra (1989:236).mengatakan bahwa "program adalah rumusan yang memuat gambaran pekerjaan yang akan dilaksanakan beserta petunjuk cara-cara pelaksanaanya". Dari berbagai pendapat diatas dapat disimpulkan bahwa yang dimaksud dengan program adalah suatu rumusan atau rancangan pemikirian yang memuat gambaran pekerjaan yang akan dilaksanakan beserta petunjuk dan cara-cara 
pelaksanaaannya (Juklak Juknis). Juklak juknis ini menjadi sangat penting bagi para implementor sebagai pegangan dalam menentukan arah kegiatan sehingga tidak melenceng dari tujuan dan sasaran program. Oleh karena itu perkembangan program dapat diartikan sebagai hasil-hasil sementara yang telah dicapai selama proses implementasi masih berlangsung. Oleh karenanya dari waktu ke waktu perkembangan suatu program bisa diamati. Apabila hasil-hasil yang dicapai senantiasa meningkat dari waktu ke waktu, berarti perkembangan program dikatakan baik, namun apabila hasil yang di dapatkan tetap, maka perkembangan program berarti stagnan atau tidak berkembang sama sekali dan bahkan bisa saja perkembangannya negatif apabila hasil-hasil kegiatan ternyata mengalami kerusakan atau berkurang. Menurut Ripley dan Franklin (dalam Winarno 2007: 145) bahwa yang dimaksud dengan kerumitan program adalah tingkat kerumitan suatu program kegiatan dilihat dari aturan program yang bersangkutan. Oleh karenanya, dinamisnya petunjuk pelaksanaan yang dibuat akan mempengaruhi berhasil atau tidaknya program yang diimplementasikan. Sedangkan menurut Warwick (dalam Supriyatno, 2010) yang dimaksud dengan kesulitan program yaitu kerumitan yang melekat pada proyek itu sendiri yang berupa faktor teknis, faktor ekonomi, pengadaan bahan dan faktor perilaku pelaksana atau masyarakat.

4. Partisipasi pihak lain (The Participation of The Other)

Maksudnya adalah partisipasi dari semua pihak yang terlibat dalam implementasi program tersebut selain para aktor yang sudah disebutkan di atas. Pihak ini bisa dari instansi pemerintahan, lembaga swasta, baik kelompok maupun individu (Anderson, 1979; Lester dan Stewart, 2000 dalam Kusumanegara, 2010). Pihak-pihak mana saja yang baik secara langsung maupun tidak langsung ikut mendukung suksesnya implementasi program SPM Dikdas Tingkat SMP di Kabupaten Purbalingga. Kekuatan peran para pihak tersebut bisa dilihat dari besarnya partisipasi dan kelompok mana yang paling berpengaruh dalam proses implementasi kebijakan (Anderson, 1979). 
5. Faktor-faktor yang tidak terkendali (The Uncontrollable Factors That All Affect Implementation).

Faktor yang tidak terkendali ini yaitu apakah ada faktor-faktor diluar teknis (yang telah melampaui batas kontrol dari implementor) yang secara tidak langsung berhubungan dengan pengimplementasian program, sehingga dapat menghambat bahkan mengagalkan implementasi program yang telah dirancang sebelumnya (Ripley dan Franklin, 1986:11).

\section{METODE PENELITIAN}

Metode penelitian yang akan digunakan dalam penelitian ini adalah metode penelitian deskriptif kualitatif. Metode penelitian deskriptif adalah penelitian yang dilakukan untuk mengetahui nilai variabel mandiri, baik satu variabel atau lebih tanpa membuat perbandingan atau menghubungkan antara satu variabel dengan variabel yang lain. Atau suatu penelitian yang berusaha menjawab pertanyaan (Sugiyono, 2007:11). Jenis penelitian deskriptif bertujuan menggambarkan secara sistematik dan akurat dari fakta dan karakteristik mengenai populasi atau bidang tertentu. Sedangkan penelitian kualitatif adalah metode penelitian yang digunakan untuk meneliti pada kondisi obyek yang alamiah (sebagai lawannya adalah eksperimen) dimana peneliti adalah sebagai instrumen kunci, teknik pengumpulan data dilakukan secara trianggulasi (gabungan), analisis data bersifat induktif, dan hasil penelitian kualitatif lebih menekankan makna daripada generalisasi (Sugiyono, 2005:1). Dari berbagai definisi di atas dapat dijelaskan bahwa metode penelitian deskriptif kualitatif adalah prosedur penelitian yang menghasilkan data deskriptif berupa kata-kata tertulis atau lisan dan perilaku yang diamati selanjutnya diinterpresentasikan oleh peneliti (Bogdan dan Taylor dalam Moleong, 2013:4).

\section{HASIL PENELITIAN DAN PEMBAHASAN}

1. Aktor-aktor yang terlibat

Dalam penelitian ini didapatkan informasi bahwa proses Implementasi SPM

Dikdas di Kabupeten Purbalingga baru dimulai sejak tahun 2015 dengan 
aktor-aktor sebagai berikut : Kepala Dinas`sebagai penanggungjawab utama suksesnya proses implementasi SPM Dikdas Tingkat SMP. Sedangkan Bagian yang paling bertanggung jawab dalam proses implementasi SPM Dikdas tingkat SMP pada Dinas` Pendidikan dan Kebudayaan adalah Bidang Pembinaan SMP selaku pelaksana dalam menjalankan tugas Kepala Dinas dalam memimpin, mengkoordinasikan, membina dan mengendalikan tugastugas dibidang pendidikan SMP. Sedangkan pada satuan pendidikan, maka kepala sekolah adalah penanggungjawab utama proses implementasi. Meskipun demikian, semua bidang dan semua orang yang berkaitan juga merasa bertanggungjawab dan ikut serta bahu membahu dalam proses implementasi SPM Dikdas Tingkat SMP. Aktor-aktor pada Bidang Pembinaan SMP yang terdiri dari satu orang Kepala Bidang, Tiga Orang Kepala Seksi Seksi dan sepuluh orang staff. Sedangkan pada satuan pendidikan (SMP) tidak ada bagian khusus yang menangani SPM Dikdas, karena semua orang ikut terlibat dalam proses implementasi. Para Aktor pada sekolah terdiri dari Satu orang Kepala Sekolah, Beberapa orang guru Mata Pelajaran, Satu Orang Kepala Tata Usaha beserta Staffnya, Beberapa tenaga khusus dan beberapa tenaga pembantu umum. Khusus untuk SMP N 6 Satu Atap Rembang Purbalingga masih dibutuhkan beberapa orang tenaga pada Bagian Tata Usaha. Jumlah aktor yang terlibat. Terdiri dari 14 orang aktor pada Bidang Pembinaan SMP, 18 orang aktor pada SMP N 6 Satu Atap Rembang Purbalingga dan 59 orang aktor pada SMP N 3 Purbalingga. Jumlah aktor yang ada sudah mencukupi sesuai dengan kebutuhan. Para aktor sudah paham akan tujuan dan sasaran SPM-Dikdas. Para Aktor sudah paham akan Tugas Pokok dan Fungsinya (Tupoksi) masing-masing. Para aktor sudah memiliki kemampuan dan keterampilan untuk mengimplementasikan kebijakan SPMDikdas tingkat SMP. Masing-masing aktor sudah berperan sesuai dengan tugas pokok dan fungsinya masing-masing, bahkan mereka saling membantu rekan yang membutuhkan meski itu bukan tugas pokok mereka, mereka bekerja sama dalam proses implementasi SPM Dikdas Tingkat SMP. Masingmasing aktor sudah sangat serius dan maksimal dalam bekerja, mereka bekerja 
tidak mengenal waktu sesuai dengan kemampuan dan tugas pokok dan fungsinya masing-masing. Berdasarkan berbagai penjelasan di atas, dapat disimpulkan bahwa para aktor implementasi SPM Dikdas Tingkat SMP pada SMP N 6 Satu Atap Rembang Purbalingga dan SMP N 3 Purbalingga sudah berhasil mengimplementasikan program SPM Dikdas dengan baik. Selain itu sesuai dengan hasil penelitian dan pengamatan terhadap para aktor yang terlibat sebagaimana diuraiakan dalam pembahasan di atas, maka didapatkan satu tesis baru bahwa variabel aktor-aktor yang terlibat sebenarnya masih terlalu sempit untuk melihat sejauh mana proses implementasi program dijalankan, ada satu variabel atau pemilihan kalimat yang lebih relevan dan lebih umum dari pada aktor-aktor yang terlibat, yaitu tersedianya Sumber Daya Manusia sebagai implementor yang dibutuhkan untuk mengimplementasikan program.

2. Kejelasan Tujuan dan Sasaran Program

Tujuan SPM-Dikdas di Kabupaten Purbalingga secara umum adalah Tersedianya sarana prasarana pendidikan yang layak, pendidik dan tenaga kependidikan yang berkualitas dan kompeten, kurikulum yang baik, sistem penilaian pendidikan yang baik, penjaminan mutu pendidikan yang baik, dan manajemen sekolah/madrasah yang mantap dan untuk memperkuat kapasitas pengelolaan pendidikan dasar di tingkat Kabupaten/ Kota/ Satuan Pendidikan dalam melakukan perencanaan penganggaran serta pengelolaan layanan-layanan pendidikan sesuai dengan standard pelayanan minimal pendidikan dasar sebagai upaya meningkatkan kualitas pendidikan dasar pada Satuan Pendidikan (sekolah) di seluruh wilayah Kabupaten Purbalingga sesuai dengan standard pelayanan minimal pendidikan dasar (SPM Dikdas) dalam rangka mencapai Standar Nasional Pendidikan (SNP) secara bertahap. Selain itu, tujuan hasil yang diharapkan yaitu membantu upaya pemerintah Indonesia untuk memperkuat sistem pendidikan dan menyelesaikan kesenjangan pendidikan antar daerah. Tujuan akhir dari SPMDikdas adalah tingginya kecerdasan masyarakat Purbalingga dan rakyat Indonesia sebagaimana dicita-citakan dalam Tujuan Nasional Indonesia. Sasaran SPM-Dikdas di Kabupaten Purbalingga adalah adalah semua sekolah 
SD/SDLB, SMP/SMPLB/ SMPT, dan SD-SMP Satu Atap (Satap), baik negeri maupun swasta di seluruh wilayah Kabupaten Purbalingga yang sudah memiliki Nomor Pokok Sekolah Nasional (NPSN) dan sudah terdata dalam sistem Data Pokok Pendidikan (Dapodik) Dinas Pendidikan dan Kebudayaan Kabupaten Purbalingga. Belum ada SOP (Standar Operating Procedures) dalam implementasi kebijakan SPM-Dikdas tingkat SMP baik pada Dinas Pendidikan dan Kebudayaan Kabupaten Purbalingga maupun pada satuan pendidikan. Para implementor sudah memiliki Program Kerja yang jelas dalam mengimplementasikan SPM Dikdas Tingkat SMP. Program kerja tersebut berisi rencana kegiatan yang akan dilaksanakan untuk satu tahun mendatang (Program kerja Tahunan) dan rencana kegiatan yang berisi rencana kegiatan untuk beberapa tahun ke depan (Program Kerja Jangka Menengah). Berdasarkan berbagai penjelasan di atas dapat disimpulkan bahwa program SPM Dikdas tingkat SMP pada SMP N 6 Satu Atap Rembang Purbalingga dan SMP N 3 Purbalingga sudah memiliki tujuan dan sasaran yang jelas yang dijabarkan lebih jelas dalam Rencana Strategi, Program Kerja atau Rencana Kerja Tahunan (RKT) dan Rencana Kegiatan dan Anggaran Sekolah. Di luar pembahasan di atas, juga berdasarkan hasil pengamatan sebagaimana tertuang dalam berbagai uraian di atas, dihasilkan satu tesis baru yaitu bahwa variabel kejelasan tujuan dan sasaran terbukti kurang memenuhi berbagai topik pembahsaan di atas, karena masih terlalu sempit dan belum bisa menjawab berbagai pertanyaan untuk mengetahui sejauh mana program diimplementasikan. Ada satu variabel yang lebih tepat dan memenuhi kriteria dalam pembahasan ini, yaitu variabel adanya aturan yang jelas sebagai pedoman para implementor dalam menjalankan berbagai kegiatan implementasi.

3. Perkembangan dan Kerumitan Program

Program SPM Dikdas Tingkat SMP bisa diimplementasikan di Kabupaten Purbalingga, khususnya pada SMP N 6 Satu Atap Rembang Purbalingga dan SMP N 3 Purbalingga. Program SPM Dikdas Tingkat SMP bukanlah jenis program yang rumit untuk diimplementasikan di Kabupaten Purbalingga. 
Faktor-faktor pendukung agar program mudah diimplementasikan diantaranya adalah aturan yang dibuat pemerintah jangan terlalu mempersulit para implementor dilapangan dalam menjalankan tugasnya, tercukupinya Sumber Daya Manusia (Implementor) yang berkualitas (berwawasan luas, cerdas dan terampil), tersedianya sarana dan prasarana, tersedia dana yang cukup. Kesulitan terbesar yang dirasakan para aktor dalam melaksanakan program adalah apabila dana yang tersedia kurang mencukupi selain itu adalah apabila menghadapi kondisi alam yang sulit sementara sarana dan prasarana yang dimiliki kurang memadai. Tidak ada kendala yang berarti bagi para aktor dalam proses implementasi program SPM Dikdas asalkan seluruh daya dukung tersedia dengan baik. Fasilitas yang sudah diterima/diberikan untuk mempermudah para aktor mengimplementasikan program adalah berupa aturan yang mempermudah, pengadaan sarana dan prasarana, pelatihanpelatihan dana kegiatan proses implementasi SPM Dikdas Tingkat SMP. Perkembangan implementasi kebijakan SPM Dikdas Tingkat SMP sudah cukup baik, secara umum untuk seluruh kabupaten purbalingga, capaian SPM Dikdas Tingkat SMP sudah mencapai 70,33\%, sedangkan untuk SMP N 6 Satu Atap Rembang sudah mencapai 67\% dan SMP N 3 Purbalingga sudah mencapai $100 \%$. Hal-hal yang di butuhkan untuk memudahkan para aktor mencapai angka capaian seratus persen adalah tersedianya seluruh daya dukung yang ada seperti kegiatan pelatihan untuk meningkatkan kualitas Sumber Daya Manusia, Pembangunan dan pengadaan sarana dan prasarana kegiatan, tersedianya dana yang cukup dengan aturan penggunaan dana yang tidak dipersulit serta partisipasi dari pihak-pihak lain yang berkaitan dengan SPM Dikdas Tingkat SMP. Dari berbagai hasil penelitian yang disesuaikan dengan hasil pengamatan langsung (observasi) dilapangan dan sesuai dengan data-data pendukung yang ada dan berdasarkan dengan berbagai pendapat baik dari pihak luar maupun dari para aktor sendiri, dapat disimpulkan bahwa proses implementasi SPM Dikdas pada Dinas Pendidikan Kabupaten Purbalingga maupun pada SMP N 6 Satu Atap Rembang Purbalingga dan SMP N 3 Purbalingga mengalami perkembangaan yang cukup baik dengan 
tingkat kerimitan yang relatif kecil. Selain itu, berdasarkan pada hasil pengamatan dalam penelitian sebagaimana tertuang dalam berbagai pernyataan di atas, mengkritisi teori Ripley dan Franklin, bahwa variabel perkembangan dan kerumitan program dalam pembahasan ini masih kurang relevan, akan lebih baik apabila perkembangan program menjadi variabel tersendiri yaitu progress implementasi program, sedangkan kerumitan program juga masuk dalam variabel faktor penghambat implementasi program.

4. Partisipasi dari Pihak Lain

Pihak-pihak yang ikut terlibat dalam proses implementasi kebijakan SPMDikdas Tingkat SMP di antaranya adalah Bakeuda, Bappelitbangda, DPU, DPRD Kabupaten Purbalingga, Pengembang, Konsultan, BPBD, TNI, Polisi, Puskesmas, Pemerintahan Desa Setempat, BPD Jateng BRI, Komite Sekolah, masyarakat sekitar dan wali murid. Peran masing-masing pihak tersebut yaitu: Badan Keuangan Daerah atau BAKEUDA berperan dalam penyedian dana dan pembiayaan lainnya, BAPPELITBANGDA berperan dalam perencanaan pembangunan gedung gedung sekolah dan segala sarana dan prasarananya, Dinas Pekerjaan Umum (DPU) berperan dalan pelaksanaan dan pengawasan penyediaan Sarana dan prasarana, baik gedung maupun jalan, DPRD Kabupaten Purbalingga berperan dalam pebuatan Kebijakan, Para Pengembang berperan dalam Pelaksana pembangunan dilapangan. Konsultant membantu melakukan perencanaan dan membantu para pekerja di lapangan. BPBD berperan dalam melakukan penanggulangan bencana alam di daerahdaerah sekitar satuan pendidikan, Polisi berperan mengadakan sosialisasi lalu lintas dan tindak kriminal lainnya, TNI berperan dalam melakukan pelatihan PBB, Paskibra dan lainnya, BPD Jateng berperan sebagai tempat mengambil dana BOS, BRI berperan sebagai tempat mengambil dana KIP, Dinas Pekerjaan Umum (DPU) berperan dalam pembangunan gedung, jalan dan jembatan, Para Pengembang berperan dalam pelaksana di lapangan dalam pengadaan sarana dan prasarana, Konsultant berperan dalam bimbingan para pekerja dalam proses pembangunan gedung, Puskesmas berperan dalam sosialisasi tentang kesehatan, pemeriksaan kesehatan siswa secara berkala dan 
imunisasi, TNI berperan dalam pelatihan beris Berbaris dan pramuka, Polisi berperan dalam sosialisasi lalu lintas, kriminalitas dan bahaya narkoba, Komite Sekolah berperan dalam pembuatan Rencana Kerja Sekolah atau program tahunan bersama dengan sekolah, selain itu mereka juga berperan aktif dalam proses pembangunan gedung sekolah, baik dalam pengawasan maupun terhun langsung dalam pengadaan kebutuhan material, Pemerintahan Desa Tanalum berperan dalam mengajukan usulan pembangunan jalan dan jembatan serta pendataan KIP dan masyarakat sekitar termasuk wali murid dalam Penerimaan Siswa Baru dan pembinaan karakter siswa di rumah dan lingkungan sekolah. Masing-masing pihak sudah berperan secara serius dan secara masksimal sesuai dengan kemampuan masing-masing. Keterlibatan pihak-pihak lain dalam proses implementasi SPM Dikdas pada SMP N 6 Satap Rembang dan SMP N 3 Purbalingga sudah cukup baik. Mereka mampu bersinergis dengan para implementor dalam menjalankan proses implementasi program sesuai dengan tugas dan tanggungjawabnya masing-masing pada instansi atau lembaganya. Hasil penelitian ini sejalan dengan penelitian Novita Wijanarti dan Slameto (dalam Evaluasi Pencapaian Standar Pelayanan Minimal berdasarkan Prinsip Good Governance di SD Negeri 4 Kaliaman Jepara, 2017) yang menyatakan bahwa keterlibata dari pihak lain terutama masyarakat, lembaga pemerintah dan lembaga swasta sangat memmbantu proses implementasi SPM Dikdas sehingga pencapaian indeks memperoleh kriteria baik, yaitu 87,4\%. Selain itu, mengkritisi teori Ropley dan Franklin dala bahasan ini, didapatkan satu tesis baru yaitu bahwa variabel partisipasi dari pihak lain berdasarkan berbagai uraian di atas akan lebih tepat jika masuk dalam variabel faktor-faktor pendukung dalam proses implementasi program. Variabel faktor pendukung menjadi satu dengan variabel faktor penghambat program, sehingga didapat variabel baru yaitu faktor-faktor pendukung dan penghambat implementasi program.

5. Faktor-faktor yang tidak terkendali

Berdasarkan berbagai hasil wawancara, hasil pengamatan langsung (observasi) dilapangan dan sesuai dengan data-data pendukung yang ada dapat 
disimpulkan bahwa terdapat dua faktor yang dihadapi oleh para implementor SPM Dikdas Tingkat SMP pada SMP N 6 Satu Atap Rembang Purbalingga dan SMP N 3 Purbalingga di Dinas Pendidikan dan Kebudayaan Kabupaten Purbalingga, yaitu Faktor Kurangnya Dana, dan Faktor Bencana Alam. Khusus untuk SMP N 3 Purbalingga faktor tak terkendali yang seringkali dihadapi hanyalah faktor kurangnya dana, karena faktor alam masih angat mendukung. Dari berbagai hasil penelitian tentang proses implementasi SPM Dikdas Tingkat SMP pada SMP N 6 Satu Atap Rembang dan SMP N 3 Purbalingga, dapat disimpulkan bahwa terdapat dua macam faktor tak terkendali yang sering menjadi penghambat dalam proses implementasi program, yaitu faktor dana dan faktor alam. Sedangkan faktor alam bisa teratasi dengan pengadaan sarana dan prasarana yang memadai, yang pada akhirnya kembali kepada faktor dana. Pada hakekatnya, semakin banyak anggaran dana akan semakin cepat dan mudah proses implementasi program dilaksanakan. Selain kesimpulan di atas, mengkritisi teori Ripley dan Franklin, didapatkan satu tesis baru, yaitu bahwa variabel faktor-faktor tak terkendali masih terlalu sempit untuk mengungkap sejauhmana proses implementasi SPM Dikdas Tingkat SMP, ada variabel yang lebih tepat dan lebih luas untuk menggantikan faktor-faktor tak terkendali, yaitu faktor-faktor tak terduga yang didalamnya terdapat faktor yang tak terkendali dan kegiatan mendadak di luar rencana kegiatan. Oleh karena itu, akan lebih tepat jika pendanaan masuk dalam variabel sendiri yaitu ketersediaan Sumber Dana dan bencana alam masuk dalam variabel faktor penghambat implementasi program. Berdasarkan berbagai pembahasan di atas didapatkan satu perspektif baru untuk mengetahui sejauh mana proses implementasi program SPM Dikdas, yaitu perspektif sejauhmana program diimplementasikan yang terdiri dari 7 variabel, yaitu Ketersediaan Sumber Daya Manusia, Adanya aturan yang jelas, Kejelasan sumber dana dan ketersediaan sumber dana, Ketersediaan perangkat utama program yang meliputi, Progress implementasi program, Faktor pendukung dan penghambat proses implementasi program, Faktor-faktor lain yang tak terduga. 


\section{KESIMPULAN}

1. Proses Implementasi SPM Dikdas Sudah dijalankan dengan cukup baik oleh para implementor, terutama pada SMP N 3 Purbalingga, hal itu juga dibuktikan dengan indeks pencapaian $100 \%$ pada indikator SPM Dikdas.. Namun untuk SMP N 6 Satu Atap Rembang Purbalingga jumlah implementornya masih kurang yaitu dibutuhkan beberapa orang tenaga pada Bagian Tata Usaha. Selain itu belum ada Tenaga Operator Komputer yang handal dan belum ada tenaga pembantu yang memiliki kemampuan keterampilan yang memadai. Sedangkan untuk tenaga guru, belum ada satu guru pun yang berstatus PNS, semua masih wiyata bakti dan sebagian besar guru belum memiliki sertifikat pendidik, padahal sertifikat pendidik bagi guru merupakan salah satu indikator pencapaian program SPM Dikdas Tigkat SMP. Selain itu, sertifikat pendidik juga menunjukkan bahwa guru sudah profesional dan memiiliki kemampuan untuk menjalankan program SPM Dikdas. Sesuai dengan hasil penelitian dan pengamatan terhadap para aktor yang terlibat, ditemukan satu variabel baru yang relevan dalam pembahasan ini yaitu Sumber Daya Manusia.

2. Tujuan Program Implementasi SPM Dikdas Sudah Cukup Jelas, namun adakalanya tujuan tidak tercapai secara maksimal karena rencana kegiatan yang dibuat masih terkesan kurang berani karena terhambat oleh ketatnya aturan dan ketersediaan sumber dana. Selain itu belum ada Standar Operating Procedure (SOP) yang jelas yang dimiliki para implementor utnuk menjalankan tugasnya. Sasaran program sudah cukup luas, namun masih ditujukan kepada sekolah-sekolah tertentu saja yang sudah terdaftar. Selain kesimpulan di atas, didapatkan satu temuan baru yaitu bahwa variabel yang lebih tepat untuk mengetahui proses implementasi sebuah kebijakan sehubungan dengan variabel ini adalah perangkat lunak yang mendukung yang bisa berupa kebijakan pemerintah, Petunjuk Teknis dan petunjuk pelaksanaan, Rencana Kegiatan yang didalamnya memuat tujuan dan sasaran program, Standar Operating Procedure (SOP) dan sebagainya. Berdasarkan 
berbagai uraian di atas, hasil pengembangan dari variabel dalam teori Ripley dan Franklin, maka ditemukan variabel baru yaitu adanya aturan yang jelas.

3. Perkembangan program SPM Dikdas Tingkat SMP sudah cukup baik, namun masih kurang cepat karena terhalang oleh sumber daya manusia yang masih belum memenuhi kriteria indikator SPM Dikdas. Selain itu pembangunan gedung-gedung sekolah dengan segala sarana dan prasarananya masih kurang cepat, padahal ketersediaan sarana dan prasarana pendidikan merupakan salah satu indikator pencapaian SPM Dikdas. Sedangkan mengeni kerumitan program, sebenarnya program SPM Dikdas tergolong program yang rumit karena membutuhkan sumber daya manusia yang cukup banyak dan dana yang besar. Sedangkan kesulitan terbesar yang dirasakan para aktor dalam melaksanakan program adalah apabila dana yang tersedia kurang mencukupi. Kerumitan lainnya yaitu apabila menghadapi kondisi alam yang sulit sementara sarana dan prasarana yang dimiliki kurang memadai. Meskipun demikian, tidak ditemukan kendala yang berarti oleh para aktor dalam menjalankan proses implementasi program SPM Dikdas selama seluruh daya dukung tersedia dengan baik. Hal-hal yang di butuhkan untuk memudahkan para aktor mencapai angka capaian seratus persen adalah tersedianya seluruh daya dukung yang ada seperti kegiatan pelatihan untuk meningkatkan kualitas Sumber Daya Manusia, Pembangunan dan pengadaan sarana dan prasarana kegiatan, tersedianya dana yang cukup dengan aturan penggunaan dana yang tidak dipersulit serta partisipasi dari pihak-pihak lain yang berkaitan dengan SPM Dikdas Tingkat SMP. Dari berbagai pernyataan di atas, ditemukan variabel baru yaitu progress implementasi program.

4. Pihak-pihak lain sudah berpartisipasi cukup baik dalam proses implementasi SPM Dikdas Tingkat SMP pada SMP N 6 Satu Atap Rembang Purbalingga dan SMP N 3 Purbalingga, namun demikian perlu koordinasi yang lebih baik antar pihak-pihak tersebut sehingga terjadi hubungan komunikasi yang lebih baik untuk memprcepat proses implementasi program. Partisipasi dari pihak lain masih kurang maksimal, karena pihak-pihak lain tersebut terkesan hanya sekedar melaksanakan berbagai kegiatan sesuai tugas dan kewajibannya saja, 
bukan karena kepedulian dan kesadaran mereka untuk mensukseskan program SPM Dikdas, hal ini disebabkan karena belum ada permintaan dan pemberitahuan yang jelas dari para aktor terhadap pihak-pihak lain tentang program SPM Dikdas. Dari berbagai uraian di atas akan lebih tepat jika partisipasi dari pihak lain masuk dalam variabel faktor-faktor pendukung dalam proses implementasi program.

5. Faktor-faktor yang tak terkendali yang dialami oleh para implementor adalah faktor dana dan faktor alam yang juga termasuk faktor-faktor yang sangat mempengaruhi proses implentasi SPM Dikdas. Biaya dianggap sebagai faktor tak terkendali karena mereka tidak mampu mencari biaya sendiri. Sumber Biaya benar-benar mengandalkan kucuran dari pemerintah daerah dan pemerintah pusat. Oleh karena itu semakin banyak dana maka semakin lancar proses implementasi program. Namun sebaliknya, semakin sedikit dana, maka semakin sulit program untuk diimplementasikan, karena program ini memang program yang memiliki banyak kegiatan yang membutuhkan banyak dana. Sementara itu dana tidak bisa dicari oleh para implementor, tapi dana harus didatangkan dari pihak lain, terutama pemerintah selaku pembuat kebijakan. Faktor alam, disebut sebagai faktor tak terkendali, karena banyak kejadian bencana alam yang terjadi di Kabupaten Purbalingga, terutama di SMP N 6 Satap Rembang yang pernah mengalami bencana longsor, sehingga tiga ruang kelas rusak di tidak memenuhi standar pelayanan minimal pendidikan lagi. Perbedaan dua faktor tersebut adalah bahwa faktor adanya biaya adalah faktor penunjang, sedangkan faktor alam yang buruk (bencana alam) adalah faktor penghambat. Demikian juga faktor kurangnya biaya atau faktor tidak adanya biaya akan menjadi faktor penghambat sedangkan faktor tidak ada bencana akan menjadi faktor penunjang. Dalam proses implementasi SPM Dikdas di dua sekolah tersebut, tampaknya faktor biaya dan alam belum bisa teratasi. Biaya yang tersedia sekarang masih sangat kurang, baik dari segi anggaran maupun serapan. Sedangkan, kondisi alam di Kabupaten Purbalingga masih rawan bancana, terutama bencana banjir dan longsor pada musim penghujan. Selain kesimpulan di atas, mengkritisi teori Ripley dan 
Franklin, maka variabel yang lebih tepat untuk menggantikan faktor-faktor tak terkendali adalah faktor-faktor tak terduga yang didalamnya terdapat faktor yang tak terkendali dan kegiatan mendadak di luar rencana kegiatan. Sedangkan pendanaan masuk dalam variabel sendiri yaitu ketersediaan Sumber Dana. Berdasarkan berbagai penjelasan di atas, dapat diambil satu kesimpulan lagi bahwa secara umum proses implementasi SPM Dikdas Tingkat SMP di Kabupaten Purbalingga studi pada SMP N 6 Satap Rembang masih kurang begitu baik, sedangkan proses implemetasi SPM Dikdas pada SMP N 3 Purbalingga sudah berjalan dengan cukup baik. Namun demikian perlu diadakan perbaikan dalam setiap variabel proses di atas agar proses implementasi menjadi lebih baik dan mendapatkan hasil yang maksimal. Berdasarkan pada hasil pengamatan dalam penelitian ditemukan variabel baru yang berbeda dengan teori warwick yang mengatakan bahwa terdapat dua faktor tak terkendali dalam setiap proses implementasi kebijakan, yaitu faktor waktu dan kepemimpinan, namun dalam hasil penelitian ini, terdapat dua faktor tak terkendali yang lebih dominan, yaitu faktor dana dan kondisi alam.

Berdasarkan pada pengamatan dan hasil penelitian, didapatkan satu perspektif baru sebagai hasil pengembangan teori Ripley dan Franklin, yaitu perspektif "Sejauhmana program diimplementasikan" atau "How the process" yang terdiri dari 7 variabel, yaitu Ketersediaan Sumber Daya Manusia, Adanya aturan yang jelas, Ketersediaan dana, Ketersediaan perangkat utama program, Progress implementasi program, Faktor pendukung dan penghambat proses implementasi program.

\section{SARAN}

1. Sehubungan dengan Aktor-aktor yang terlibat ; sebaiknya kualitas Sumber daya Manusia yang ada senantiasa ditingkatkan dengan terus mengadakan pendidikan dan pelatihan tentang Implementasi SPM Dikdas. Pendidikan berguna untuk meningkatkan pengetahuan dan pemahaman para para aktor akan tujuan dan sasaran SPM Dikdas serta tugas pokok dan fungsi masingmasing para aktor. Pelatihan berguna untuk meningkatkan keterampilan para 
aktor. Bimbingan harus selalu dilakukan kepada para implementor di lapangan. Akan lebih baik jika selalu mengadakan koordinasi dalam pelaksanaan proses implementasi. Pengawasan dilakukan bukan untuk mencari kesalahan implementor, tetapi untuk mencari para implementor yang membutuhkan bantuan dan bimbingan. Para implementor perlu selalu dimotivasi dengan berbagai penghargaan atas hasil kerja keras mereka agar mereka tetap bekerja secara serius dan maksimal. Sebaiknya seluruh kebutuhan tenaga secepatnya dipenuhi, karena kekurangan tenaga kerja bisa menghambat proses implementasi SPM Dikdas.

2. Sehubungan dengan tujuan dan sasaran program; sebaiknya dibuat rencana kegiatan yang berkualitas, efektif dan efisien. Akan lebih baik lagi jika senantiasa berinovasi dan berkreasi. Proses implementasi SPM Dikdas Tingkat SMP membutuhkan kreatifitas yang tinggi. Setelah rencana kegiatan dan rencana anggaran biaya kegiatan dibuat (baik program kerja tahunan maupun rencana pembangunan jangka menengah), sebaiknya rencana kegiatan yang telah dibuat tersebut segera dilaksanakan semaksimal mungkin secara bertahap hingga terlaksana $100 \%$.

3. Sehubungan dengan perkembangan program dalam proses implementasi SPM Dikdas Tingkat SMP ; sebaiknya semua kebutuhan Satuan Pendidikan (SMP) terutama 27 butir Indeks Pencapaian yang menjadi indikator berhasil tidaknya program SPM Dikdas di upayakan untuk dipenuhi secepatnya agar proses implementasi program bisa berkembang cepat. Beberapa indikator yang harus mendesak diadakan adalah pengadaan sumber daya manusia yang berkualitas, pengadaan buku-buku sekolah termasuk bank soal ulangan harian, ulangan semester sampai ujian nasional dan lebih khusus lagi pemenuhan sarana dan prasarana pendidikan seperti gedung sekolah, meubelair dan sebagainya.

4. Sehubungan dengan partisipasi dengan pihak lain ; sebaiknya para implementor menjalin hubungan yang lebih baik lagi dengan pihak lain, sehingga pihak-pihak lain lebih mudah diajak untuk berpartisipasi bahkan lebih sering berpatisipasi dalam rangka memperlancar proses implementasi kebijakan SPM Dikdas Tingkat SMP di Kabupaten Purbalingga sehingga 
pemenuhan Standar Pelayanan Minimum Pendidikan Dasar Tingkat SMP bisa terwujud seratus persen sesuai dengan Standar Nasional Pendidikan.

5. Sehubungan dengan faktor-faktor yang tak terkendali ; Faktor yang pertama adalah faktor dana yang merupakan unsur vital dan terpenting dalam setiap program kebijakan. Tanpa adanya dana, program SPM Dikdas Tingkat SMP tidak akan berjalan. Untuk mempermudah dan memperlancar proses implementasi program, sebiknya disediakan anggaran dana yang cukup. Anggaran dana harus mencukupi seluruh biaya kegiatan, bahkan bila perlu lebih sedikit dari kebutuhan yang sesungguhnya, karena program ini memiliki banyak kegiatan yang membutuhkan banyak biaya, termasuk dana untuk pengadaan Sumber Daya Manusia dan pengadaan sarana dan prasarana. Sebaiknya pencairan dana pun lebih dipermudah dan dipercepat, jangan terlalu berbelit karena bisa menghambat proses implementasi. Pengawasan penggunaan dana akan lebih baik ditujukan bukan untuk mengurangi keberanian para implementor dalam berinovasi dan berkreasi dalam proses implementasi, tapi lebih ditujukan pada pencegahan penyalahgunaan anggaran oleh para implementor. Faktor yang tak terkendali yang kedua adalah faktor alam, termasuk apabila terjadi bencana alam. Oleh karenanya, selain dibutuhkan kecanggihan ilmu dan teknologi untuk menghadapi alam, strategi penentuan lokasi kegiatan juga perlu diperhatikan. Sebaiknya jangan melakukan kegiatan pada daerah-daerah yang rawan bencana seperti banjir dan longsor, namun apabila memang terpaksa harus dilakukan di daerah tersebut, misal pembangunan gedung sekolah pada suatu desa terpencil yang rawan bencana, maka pengadaan ilmu dan teknologi harus dipenuhi.

\section{DAFTAR PUSTAKA}

Anderson, James E. 1979. Public Policy Making. Nelson Hall Publisher, Chicago.

Indiahono, Dwiyanto. 2009, Kebijakan Publik Berbasis Dynamic Policy Analisys. Gaya Media. Yogyakarta. 
Kusumanegara, Solahuddin. 2010. Model dan Aktor dalamProses Kebijakan Publik. Gava Media. Yogyakarta.

Moleong, Lexy J. 2012, Metode Penelitian Kualitatif Edisi Revisi. PT Remaja Rosdakarya. Bandung.

Purwanto, A. Erwan dan Dyah R Sulistyastuti. 2012. Implementasi Kebijakan Publik dan Aplikasinya di Indonesia. Gava Media. Yogyakarta.

Ripley, B. Randall dan Franklin, Grace. A. 1986. Policy Implementation and Bureaucracy. Dorsey Press, Chicago.

Subarsono, AG. 2006, Analisis Kebijakan Publik Konsep, Teori dan Aplikasi. Pustaka Pelajar, Yogyakarta.

Sugiyono. 2007, Metode Penelitian Kuantitatif dan Kualitatif dan $R \& D$. Alfabeta Bandung, Bandung.

Supriyatno, 2010. Analisis Implementasi Kebijakan Sekolah Gratis. Fakultas Sospol Universitas Indonesia. Jakarta.

Wibawa Samodra, Yuyun Purbokusumo, Agus Pramusinto. 1978. Evaluasi Kebijakan Publik. Raja Grafindo Persada. Jakarta

Winarno, Budi. 2007, Kebijakan Publik : Teory dan Proses, Cetakan Kedua. Media Perssindo. Yogyakarta.

Wijanarti, Novita dan Slameto, 2017. Journal. "Evaluasi Pencapaian Standar Pelayanan Minimal Berdasarkan Prinsip Good Governance di SD Negeri 4 Kaliaman Jepara”. Jurnal Kependidikan Triadik Volume 12, No. 1. Tahun 2017

Westra, Laura. 1989. Journal : The Ethics of Environmental Holism. Jurnal Nasional Tahun 1989. Diiakses melalui: http://jurnalnasional.westra 1989/ index.php/ian/article/viewFile/12/21 